\title{
Who Are the Visitors of Forest Park Grmoščica and What Are Their Needs? Results of Quantitative Exploratory Survey
}

\author{
Martina Kičićc,*, Ana Marija Marin ${ }^{1}$, Dijana Vuletić ${ }^{1}$, Ivana Kaliger ${ }^{2}$, Ninoslav Matošević ${ }^{2}$, Sergej Šimpraga ${ }^{3}$, \\ Silvija Krajter Ostoić ${ }^{1}$
}

(1) Croatian Forest Research Institute, Department for International Scientific Cooperation in Southeast Europe - EFISEE, Cvjetno naselje 41, HR-10450 Jastrebarsko, Croatia; (2) Croatian Forests Ltd., Forest Administration Zagreb, Operational unit Urban Forestry, HR-10000 Zagreb, Zagreb; (3) City of Zagreb, City Office for Agriculture and Forestry, Avenija Dubrovnik 12/IV, HR-10000 Zagreb, Croatia.

* Correspondence: e-mail: martinak@sumins.hr
Citation: Kičić M, Marin AM, Vuletić D, Kaliger I, Matošević N, Šimpraga S, Krajter Ostoić S, 2020. Who Are the Visitors of Forest Park Grmoščica and What Are Their Needs? Results of Quantitative Exploratory Survey. Southeast Eur for 11(2): 169-180. https://doi. org/10.15177/seefor.20-19.

Received: 7 Oct 2020; Revised: 14 Nov 2020; Accepted: 23 Nov 2020; Published online: 14 Dec 2020

\begin{abstract}
Forest Park Grmoščica is an important part of urban green infrastructure for the citizens of the western part of the city of Zagreb. To enhance the quality of management of the forest park to the satisfaction of its daily users, it is important to know their socio-demographic characteristics, visiting behaviour, recreational activities, as well as their perception of the forest park. The survey for users of the Forest Park Grmoščica was developed within the INTERREG DANUBE's URBforDAN project. It was filled out by visitors of the forest park using on-site face-to-face method and was also available online. The results of the survey provided information about the users of the Forest Park Grmoščica, their socio-demographic data, visiting habits and perception. Also, the typology of users was given depending on the activities they undertake in the forest park (cyclists, joggers, visitors who spend time in Forest Park Grmoščica with their families, and pet walkers) and their main characteristics. The obtained data can improve the management of the Forest Park Grmoščica in such a way that it fulfils its social and ecological function and is adapted to the needs of its users.
\end{abstract}

Keywords: urban forestry; participatory planning; visitors' needs; survey

\section{INTRODUCTION}

Urban forests are an important part of urban green infrastructure. Their importance is growing with the expanding number of people living in urban areas and considering the number of benefits they provide to urban dwellers (Haase et al. 2014). Among those benefits, cultural ecosystem services provided by urban green spaces are those which urban dwellers recognize as important, mostly because of their recreational potential (Dou et al. 2017). Research shows the importance of having accessible and well-maintained urban green space with facilities for different types of users at close distance to their home (Krajter Ostoić et al. 2020a). Sustainable forest management implies not only sustainable wood and biomass production but also attention to the permanent provision of forest ecosystem services. Hence, forestry experts encounter requests to consider users' needs when planning for future forest management in urban areas (Bethmann et al. 2018).

Research on the recreational use of forests in relation to human needs and preferences has long been present in Europe's scientific literature based on review by Ciesielski and Stereńczak (2018). Also, based on to-date research, urban forests and forest parks are among better-explored elements of urban green infrastructure in Croatia. However, social perspectives (use, perception, preferences, attitudes) are less addressed in comparison to other topics such as green space planning and design or green space inventory (Krajter Ostoić et al. 2020b). A number of factors influence forest's recreational value. Some of them are related 
to forest characteristics and others to characteristics of the visitors (Agimass et al. 2017). Forest characteristics influencing their recreational use are forest area accessibility, forest appearance and forest management type, as well as forest terrain characteristics (Ciesielski and Stereńczak 2018, Gerstenberg et al. 2020). Furthermore, users' sociodemographic characteristics such as age and achieved level of education or having a dog can influence recreational use of forests (e.g. Roovers et al. 2002, Arnberger and Eder 2007, Karanikola et al. 2017). Having different user groups with different expectations and needs, who use the same space at the same time can lead to negative consequences, such as overcrowding, or contribute to conflicts among the users (Arnberger 2006). Understanding different users' behaviour and needs can facilitate mediation among them, resulting in better forest management (Larondelle and Haase 2017).

In Zagreb, qualitative research on the sample of citizens shows that they perceive various types of tree-based urban green space, especially forests and forest parks, as holders of different cultural ecosystem services, including recreation (Krajter Ostoić et al. 2020a). The same research shows that forests provide more recreational opportunities than other types of urban green space, meaning that people reported more recreational activities they undertake in them. Expectedly, walking is the most important recreational activity in forests along with jogging and cycling, while activities such as hunting and mushroom picking are specific only to forests as such.

In the City of Zagreb, there are 22 forest parks. Their total surface area is 356 ha of which 185 ha is state-owned and 171 ha is privately owned (Matic 2010). Regardless of ownership, people in Croatia can use forests for rest and recreational purposes. Forest parks in the City of Zagreb are managed by Croatian Forests Ltd., Forest Administration Zagreb, Operational Unit Horticulture, while management of privately owned forests is the responsibility of their owners (Krajter Ostoić 2013). The City of Zagreb also takes care of the maintenance of the forest parks based on annual financial plans that finance adapted management of forest parks, while long-term planning and management of forest parks in the city of Zagreb is based on Forest Management Plan (2014 - 2023) made by Croatian Forests Ltd. for all forest parks in Zagreb as one management unit (privately and state-owned). Although there is no obligation for including the public into planning and management process with regard to urban forests, there is common practice in Croatia that forest management plans are presented to the interested public in the form of a public exhibition, where all those who are interested can see draft forest management plan, or in the form of a public presentation, where all those who are interested can join the presentation and give comments. When it comes to urban green spaces, in Croatia there is neither obligation for monitoring visitors of urban green spaces nor obligation for conducting surveys with them when designing new green spaces (Krajter Ostoić 2013). This can result in spaces that do not correspond with users' needs and habits and can consequently lead to conflicts among users or discourage users from using such urban green space.
The City of Zagreb and Croatian Forests Ltd. are project partners in INTERREG DANUBE's project "Management and Utilization of Urban Forests as Natural Heritage in Danube Cities" (URBforDAN) (URBforDAN 2020). Main goals of the project are to set new standards in the sustainable urban forest management, to develop internationally applicable urban forest management plans and to improve visitors' experience. There are 16 project partners from 10 countries. The project's focus area for the City of Zagreb is Forest Park Grmoščica. In Grmoščica the aim is to improve the provision of recreational and educational services using a participatory planning approach. Three workshops with local stakeholders representing the local community, local sports associations, local authority, local public school, and representatives of forest administration have been held within the URBforDAN project.

Participatory planning in urban forest management implies involvement of relevant stakeholders into the planning process. The advantage of such approach is that participation of all relevant stakeholders allows the process to be democratic and fair as well as transparent (Reed 2008). The author also states that stakeholders' participation can improve the quality of environmental decisions by broadening gathered information. When it comes to urban forest management, adopting public values into management practice can in future lead to increasing citizen participation as well as better addressing of climate change issues (Ordóñez Barona 2015). There is also a learning advantage with citizen's participation because engaging in matters related to forest management can lead to increasing one's knowledge and shaping new ways of interpretation (Bethmann et al. 2018). Previous research on the governance of urban forests in the City of Zagreb based on in-depth interviews with stakeholders has noted that some of the stakeholders indicate participation as one of the elements of governance that needs to be improved (Krajter Ostoić 2013).

Site-specific research such as the one presented on forest park visitors, their characteristics, preferences and views are scarce in the City of Zagreb and in Croatia in general (Krajter Ostoić et al. 2020b). Therefore, this research adds valuable information for improving future forest park management in Zagreb. We believe that the results of our study can inform urban forest managers about urban forests' visitors, their characteristics and visiting behaviour with aim to incorporate these findings into future planning practice or encourage new similar research in the future. This paper presents the results of the conducted questionnaire survey on the visitors and users of Forest Park Grmoščica, with the answers to the following research questions:

1. Which are the main characteristics of Forest Park Grmoščica's users?

2. What is their visiting behaviour?

3. Which are the main characteristics and visiting behaviour of most frequent forest park's user types?

4. What are the problems that forest park users perceive and what are their suggestions for improving current forest park state? 


\section{MATERIALS AND METHODS}

\section{Study Area}

The study area is Forest Park Grmoščica in the City of Zagreb, capital of the Republic of Croatia (Figure 1). Forest Park Grmoščica is located in the northwest of Zagreb at the border between city districts of Črnomerec and PodsusedVrapče. It extends between Vrapčak stream on the west, Kustošak stream on the east, llica Street on the south and Graberje Road on the north (Figure 1). It is 53.3 ha in size and the highest point of the forest park is at $240 \mathrm{~m}$ above sea level. Of the total surface area, 10.8 ha is privately owned. Few different forest stands can be encountered in the forest park out of which the most represented are: sessile oak with beech, common hornbeam and other tree species and black locust mixed with sessile oak, common hornbeam and other species (Anić and Oršanić 2010). At the moment of drafting this paper there were about $1000 \mathrm{~m}$ of forest paths, six benches and an observation deck in the forest park (Posavec 2020). Grmoščica was for a long time in the condition that could not satisfy the needs of the local population (Šimpraga 2011). However, its recreational and ecological potential as part of the network of green spaces in the city of Zagreb has been recognised (Mravunac 2015). URBforDAN project aims at enhancing the forest park's management through improving forest park's recreational role by providing adequate infrastructure adapted to different types of users.

\section{Survey}

For the purpose of this project, a survey for the users of Forest Park Grmoščica was developed. A survey design allows for quantification and generalization of populations' attitudes and opinions by studying its sample (Creswell 2003). Therefore, it is a suitable method to use when studying a forest park with its numerous users. Literature review on the human relationship with urban green spaces indicates that survey is the most common method used in research on users' preferences and perceptions (Kabisch et al. 2015). Furthermore, the survey was also used as a method of data collection about characteristics and preferences of users visiting urban forests or forests with emphasised recreational functions in multiple studies with one or more individual forests (Roovers et al. 2002, Aasetre et al. 2016, Larondelle and Haase 2017, Meyer et al. 2019), or in national research on forest recreation (Getzner and Meyerhoff 2020, Šodková et al. 2020). The survey used for the purpose of this research was developed within URBforDAN project, translated into Croatian language, and adapted to specific forest park conditions (see Supplementary File 1). It is comprised of 14 questions dealing with socio-demographic characteristics of users, activities they undertake when visiting the forest park, their visiting habits regarding visiting Forest Park Grmoščica, as well as the suggestions concerning the enhancement of its management. Data was collected between November 2018 and April 2019 by applying a mixed-mode approach that combined face-to-face and online data collecting. The main goal when using mixed-mode data collection is to reduce survey error by balancing one method's shortcomings (De Leeuw 2005). In our case, the rationale was to allow for usual users who were not on the site at the moment of data collection to answer the survey and be included in research to minimise the bias. Also, the survey was conducted in the less favourable period of the year (late autumn and winter) when usually there is fewer visitors in urban green spaces. Nevertheless, when using mixed-mode approach, particularly in online data collection, completely overcoming the bias is not guaranteed (Larondelle and Haase 2017).

Employees of Croatian Forests Ltd. carried out faceto-face data collection with users on-site, while the same
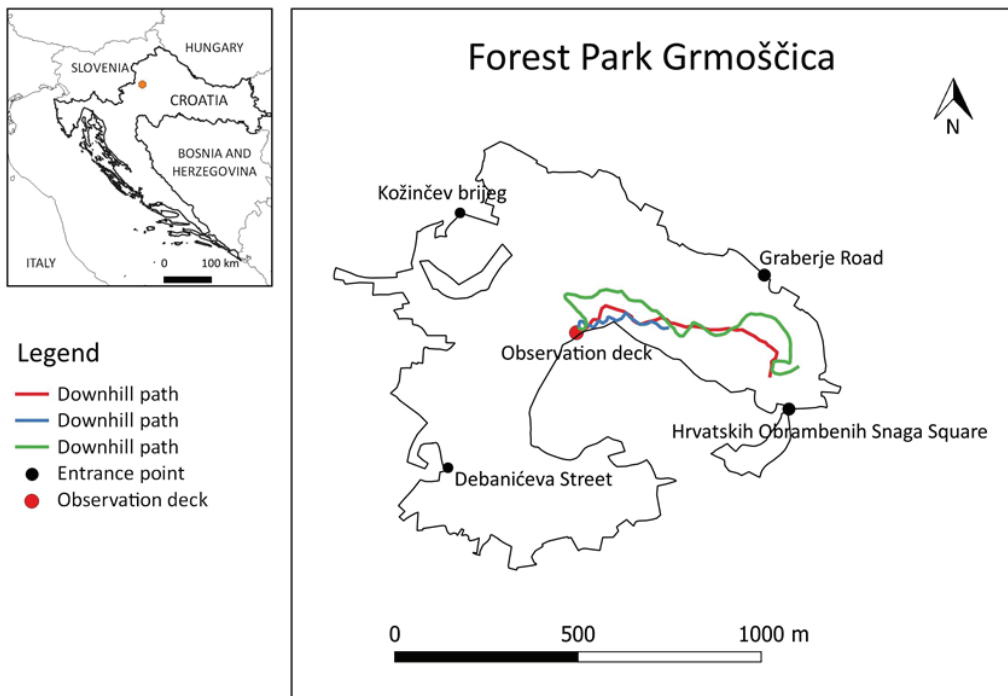

Figure 1. Forest Park Grmoščica at the beginning of URBforDAN project (2018). Country borders are based on EuroGraphics and UNFAO, @EuroGraphics. 
survey was available online at 1KA (1KA 2018) platform. The survey was also taken by participants at workshops organized within the project with different stakeholders and types of users. Information about the survey with the link to it was also communicated on the project's webpage. Data collected by face-to-face interviews on-site and during workshops was inserted into 1KA survey to have all data in one database.

Descriptive statistics was performed on collected data using R (v.3.6.2) (R Core Team 2019), while answers to openended questions were coded and presented accordingly. Subsequently, users have been divided into categories concerning types of stated specific recreational activities they undertake and their ranking. General users' main characteristics have been presented as well.

\section{RESULTS}

In total, 149 people participated in the survey. Out of that number, 99 surveys (66.4\%) have been completely (91) or partially (8) completed and used for further analysis.

\section{Socio-Demographic Characteristics}

There was a similar representation of females and males in the sample (Table 1). About one third of respondents were in the age group 45-60, while the least number of respondents were older than 60 . Two thirds of the respondents had a faculty degree. Around $80 \%$ of the respondents were employed or private business owners. Most respondents stated that they lived in Zagreb. Around one fifth of respondents lived close to Forest Park Grmoščica (up to $1 \mathrm{~km}$ to Grmoščica), and the same share stated that they lived up to $3 \mathrm{~km}$ to Grmoščica.

\section{Visiting Behaviour of Users of Forest Park Grmoščica}

The highest number of the respondents stated that they visited Forest Park Grmoščica several times per year, while the least of the respondents visited every day (Table 2). However, cumulatively close to a quarter of the respondents state that they visit forest park at least once per week. Interestingly, users in the younger age group (18-30) reported more frequent visits to Grmoščica, where $82 \%$ of them stated that they visit Grmoščica at least once a month, with $40 \%$ of them reporting visiting Grmoščica several times a month and $25 \%$ several times per week. Users in age groups 30-45 and 45-60 mainly stated that they visit Grmoščica several times a year. Two-thirds of the respondents live at a distance of up to $5 \mathrm{~km}$ from Forest Park Grmoščica. Among those, the ones who live in a proximity to Forest Park Grmoščica (up to $1 \mathrm{~km}$ and 1-2 $\mathrm{km}$ ) reported more frequent visiting behaviour than those

Table 1. Sociodemographic description of the sample ( $N=99)$.

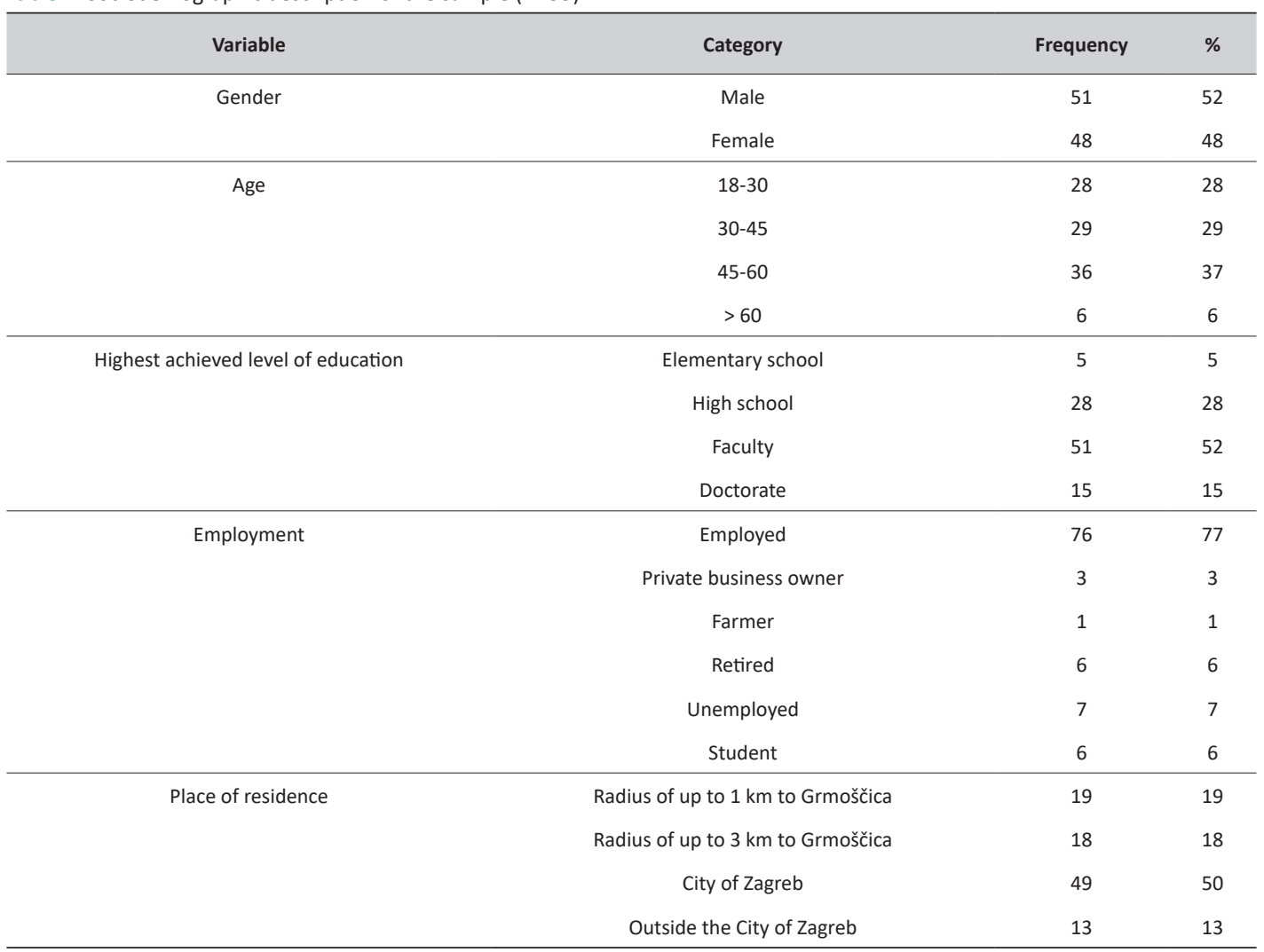


who live at a distance of $2-5 \mathrm{~km}$ and more than $5 \mathrm{~km}$, where the respondents usually expressed that they visited forest park several times a year. Car was the most preferred mean of transportation for our respondents. However, about the same share were those who arrived on foot or by bicycle, while the least number of respondents used public transportation. The majority of users who stated that their distance to the nearest entry to Grmoščica is up to $1 \mathrm{~km}$ or 1-2 km as main way of arrival said on foot or by bicycle $58 \%$ of them who live at the distance of up to $1 \mathrm{~km}$ reached Grmoščica on foot and 54\% of them at the distance of $1-2 \mathrm{~km}$ reached Grmoščica using a bicycle. Those who live at 2-5 km to the nearest entrance used all the means of transportation equally, while those who stated that they lived more than $5 \mathrm{~km}$ from the nearest entrance predominantly reported using the car as way of transportation (72\%). Comparing the reported visiting frequency of the respondents and their way of arrival to Grmoščica we can claim that out of those who reached Grmoščica on foot, using public transportation or by car the majority of them stated visiting several times per year. Nevertheless those who reached Grmoščica riding a bicycle report more frequent visiting behaviour, with $78 \%$ of them visiting several times per week, once a week or several times a month. Out of four offered possible entrances into the forest park (Figure 1), visitors mostly use the entrances from Ilica Street. Regardless of the frequency of visit, more than half of the respondents spent one to two hours in the forest park and the least number of them spent more than 5 hours in the forest park.

When asked about the activities they undertake during the visit to Forest Park Grmoščica, the respondents had a multiple-choice closed-ended question. They were also asked to rank multiple activities where 1 was the most important activity and 12 the least. The highest number of the respondents stated that they visited Forest Park Grmoščica to spend quality time with their family, then for pet walking, biking, hiking and jogging (Figure 2). The smaller number of them stated collecting forest products, forestry work, downhill mountain biking, scientific work, education in nature, taking pictures of nature, and horseback riding.

Table 2. Visiting behaviour of users of Forest Park Grmoščica ( $N=99$ )

\begin{tabular}{|c|c|c|c|}
\hline Variable & Category & Frequency & $\%$ \\
\hline \multirow[t]{5}{*}{ Frequency of visit } & Every day & 6 & 6 \\
\hline & Several times per week & 12 & 12 \\
\hline & Once per week & 8 & 8 \\
\hline & Once per month & 8 & 8 \\
\hline & Several times per year & 45 & 46 \\
\hline Distance to the nearest & Up to $1 \mathrm{~km}$ & 19 & 19 \\
\hline \multirow[t]{2}{*}{ entrance to Grmoščica } & $1-2 \mathrm{~km}$ & 13 & 13 \\
\hline & More than $5 \mathrm{~km}$ & 36 & 37 \\
\hline \multirow[t]{4}{*}{ Way of arrival to Grmoščica } & On foot & 22 & 22 \\
\hline & -By bicycle & 23 & 23 \\
\hline & Using public transportation & 14 & 14 \\
\hline & By car & 40 & 41 \\
\hline \multirow[t]{4}{*}{ Entrance } & Ilica (Debanićeva Street) & 26 & 26 \\
\hline & Ilica (Hrvatske Obrambene Snage Square) & 32 & 33 \\
\hline & Graberje Road & 22 & 22 \\
\hline & Kožinčev brijeg & 19 & 19 \\
\hline \multirow{4}{*}{ Duration of visit } & $1-2 h$ & 51 & 52 \\
\hline & $2-5 h$ & 19 & 19 \\
\hline & More than $5 \mathrm{~h}$ & 5 & 5 \\
\hline & NA & 8 & 8 \\
\hline
\end{tabular}




\section{Typology of Visitors}

With regard to stated activities the respondents undertake during the visit to Forest Park Grmoščica, they were classified into the following types of users: cyclists, joggers, pet walkers and visitors who spend time in Forest Park Grmoščica with their families. Respecting numerous functions of the forest park we decided to ground our typology of users on those activities that were preferable for the respondents in our sample, i.e. spending quality time with family, pet walking, biking and jogging. We decided to exclude hiking, although highly ranked, in favour of jogging because jogging is for more respondents the most important reason for visiting than for those who hike. In each type we included those respondents who ranked the afore mentioned activities as reason number 1, 2 or 3 for visiting the forest park. For each type of users, we provided sociodemographic characteristics, visiting habits and perception of their activity regarding possible conflicts with other users and negative impact on nature (Table 3 ).

Cyclists

Mostly, users in the cyclist category are in the age group between 18 and 30 years (Table 3). The highest achieved education level for most cyclists is faculty. The majority are employed and the highest number of them (82\%) stated that they lived in a radius of up to $5 \mathrm{~km}$ to the nearest entrance to Forest Park Grmoščica. The highest number of cyclists stated that they visited Grmoščica several times per week or several times per month and to a lesser extent once a month or every day. Out of those who reported living in the proximity of $1 \mathrm{~km}$ to Grmoščica $67 \%$ of them visit it several times per week, out of those who reported living in a radius of $1-2 \mathrm{~km}$ to Grmoščica $63 \%$ of them reported visiting at least once a week or frequently, and those who live the furthest visit it least frequently, meaning $60 \%$ of those living more than $5 \mathrm{~km}$ to the nearest entry visited the forest several times a year. They predominantly arrived in Grmoščica by bicycle, but also by car or public transportation. Those who live in a radius of up to $5 \mathrm{~km}$ of entrance to Grmoščica expectedly arrived by bicycle, while the minority of them who arrive from more than $5 \mathrm{~km}$ to the nearest entrance used a car to reach the forest park. On average they spend in Grmoščica between one and two hours, and only a few stated spending between two and five hours or more.

Most cyclists did not perceive their activities as conflicting with other visitors. Some said that it might cause conflicts with walkers. None perceived their activities harmful to nature.

Joggers

Joggers were mainly in the age groups $18-30$ and $45-60$, and to a lesser extent in the age groups 30-45 and older than 60 (Table 3). Joggers were for the most part employed and with a faculty degree. The most joggers came to the forest park from a distance of up to $5 \mathrm{~km}$ to the nearest entrance, only a third of them came from a greater distance. Joggers often reported visiting Grmoščica several times per year or several times per month. The joggers who lived at a distance of up to $1 \mathrm{~km}$ from the nearest entrance reported weekly (at least once a week) visits to the forest park, those at a distance of 1-2 km visit several times a month, those at a distance of 2-5 km several times a year, while those who live at a distance greater than $5 \mathrm{~km}$ reported visits weekly, monthly or yearly in similar share. They arrive in Grmoščica using public transportation, car, or bicycle, and most rarely on foot. Arriving using a bicycle, public transportation or by car was reported in similar shares, although those who came from a distance of up to $1 \mathrm{~km}$ mostly used a bicycle, while those from a distance of 1-2 km used a bicycle or car. Many of the joggers from a distance of 2-5 km came using public transportation, and those who needed to cross more than 5 $\mathrm{km}$ to Grmoščica used public transportation or a car. Usually, they spent between one and two hours in the forest park.

None of the joggers stated that their activities in Grmoščica might create conflict with other users, or that their activities could have a negative impact on nature, mostly because they did not leave trash in the forest park.

Figure 2. Activities of visitors of Forest Park Grmoščica and their ranking based on the relative importance (N=99).

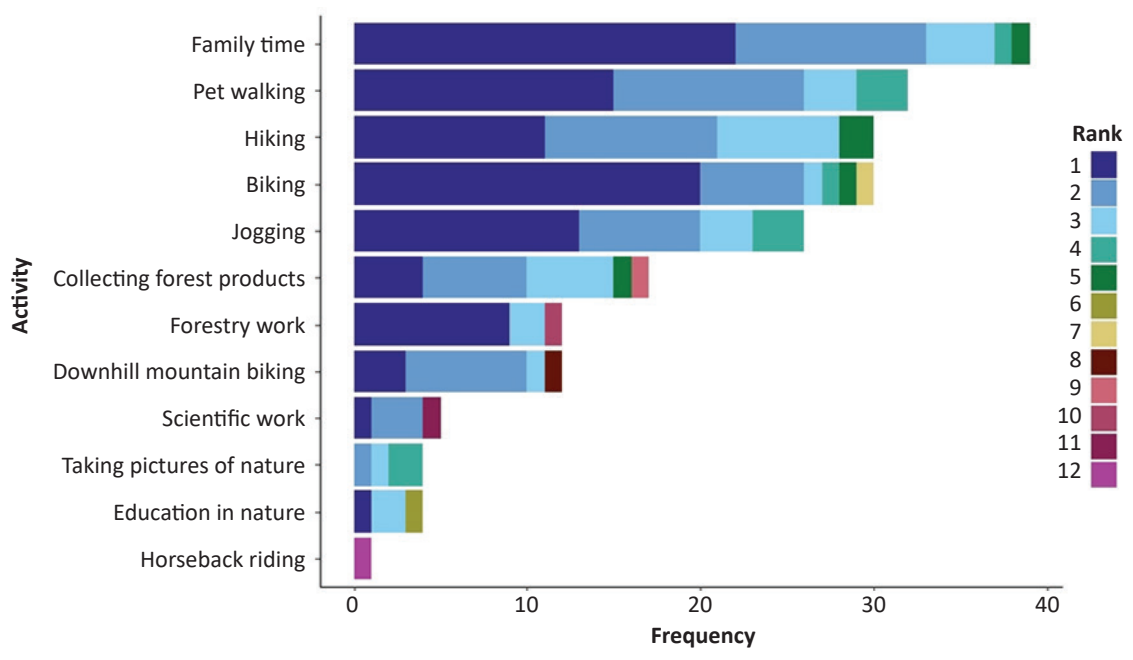


Table 3. Characteristics and visiting behaviour of different types of visitors in Forest Park Grmoščica $\left(N_{c y c}=27, N_{J O G G}=23, N_{P W}=29, N_{F A M}=37\right.$ ).

\begin{tabular}{|c|c|c|c|c|c|}
\hline \multirow[b]{2}{*}{ Variable } & \multirow[b]{2}{*}{ Category } & \multicolumn{4}{|c|}{ Users } \\
\hline & & $\begin{array}{l}\text { CYC } \\
(\%)\end{array}$ & $\begin{array}{c}\text { JOGG } \\
(\%)\end{array}$ & $\begin{array}{l}\text { PW } \\
(\%)\end{array}$ & $\begin{array}{c}\text { FAM } \\
(\%)\end{array}$ \\
\hline \multirow[t]{4}{*}{ Age } & $18-30$ & 48 & 48 & 24 & 13 \\
\hline & $30-45$ & 37 & 13 & 21 & 27 \\
\hline & $45-60$ & 15 & 39 & 48 & 49 \\
\hline & $>60$ & 0 & 0 & 7 & 11 \\
\hline \multirow[t]{4}{*}{ Highest achieved level of education } & Elementary school & 7.5 & 0 & 4 & 0 \\
\hline & High school & 33 & 35 & 24 & 16 \\
\hline & Faculty & 52 & 48 & 55 & 65 \\
\hline & Doctorate & 7.5 & 17 & 17 & 19 \\
\hline \multirow[t]{6}{*}{ Employment } & Employed & 78 & 83 & 66 & 86 \\
\hline & Private business owner & 0 & 0 & 10 & 0 \\
\hline & Farmer & 4 & 0 & 0 & 0 \\
\hline & Retired & 0 & 0 & 7 & 8 \\
\hline & Unemployed & 7 & 13 & 3 & 3 \\
\hline & Student & 11 & 4 & 14 & 3 \\
\hline Distance to the nearest & Up to $1 \mathrm{~km}$ & 22 & 17 & 31 & 21.5 \\
\hline \multirow[t]{3}{*}{ entrance to Grmoščica } & $1-2 \mathrm{~km}$ & 30 & 13 & 14 & 11 \\
\hline & $2-5 \mathrm{~km}$ & 30 & 39 & 31 & 21.5 \\
\hline & More than $5 \mathrm{~km}$ & 18 & 31 & 24 & 46 \\
\hline \multirow[t]{6}{*}{ Frequency of visits } & Every day & 3 & 4 & 14 & 3 \\
\hline & Several times per week & 22 & 13 & 21 & 3 \\
\hline & Once per week & 19 & 9 & 10 & 5 \\
\hline & Several times per month & 26 & 35 & 10 & 16 \\
\hline & Once per month & 11 & 0 & 7 & 5 \\
\hline & Several times per year & 19 & 39 & 38 & 68 \\
\hline \multirow[t]{4}{*}{ Way of arrival to Grmoščica } & On foot & 0 & 4 & 38 & 30 \\
\hline & By bicycle & 78 & 30.5 & 21 & 3 \\
\hline & Using public transportation & 3 & 35 & 7 & 19 \\
\hline & By car & 19 & 30.5 & 34 & 48 \\
\hline \multirow[t]{5}{*}{ Duration of visits } & Up to $1 \mathrm{~h}$ & 4 & 17 & 24 & 8 \\
\hline & $1-2 \mathrm{~h}$ & 70 & 48 & 62 & 62 \\
\hline & $2-5 \mathrm{~h}$ & 15 & 26 & 14 & 19 \\
\hline & More than $5 \mathrm{~h}$ & 4 & 4.5 & 0 & 5.5 \\
\hline & NA & 7 & 4.5 & 0 & 5.5 \\
\hline \multirow[t]{3}{*}{ Conflicts with other users } & Yes & 15 & 0 & 14 & 8 \\
\hline & No & 78 & 96 & 86 & 87 \\
\hline & NA & 7 & 4 & 0 & 5 \\
\hline \multirow[t]{3}{*}{ Negative impact on the nature } & Yes & 0 & 0 & 0 & 0 \\
\hline & No & 93 & 96 & 100 & 95 \\
\hline & NA & 7 & 4 & 0 & 5 \\
\hline
\end{tabular}

CYC - cyclists, JOGG - joggers, PW - pet walkers, FAM - visitors who spend time in the forest park with their families 


\section{Pet Walkers}

Most of the visitors in this category were in the age group 45-60 (Table 3). For most of them highest achieved education level is faculty and the majority of them are employed. More than half of pet walkers arrive in Grmoščica from a distance of up to $5 \mathrm{~km}$, the rest of them stated arriving from a distance greater of $5 \mathrm{~km}$. Although the highest number of pet walkers stated visiting Grmoščica a few times annually, more than half of them visited Grmoščica more frequently (every day, one or several times per week and several times per month). When considering visiting behaviour of pet walkers with regard to distance from the nearest entry to Grmoščica, we can state that of those pet walkers who reported living at a distance of $1 \mathrm{~km}$ to the nearest entry $89 \%$ of them visit Grmoščica at least several times a month, $50 \%$ of those who live at a distance of $1-2$ $\mathrm{km}$ reported using forest park once or several time a week, $56 \%$ of those who live at a distance of $2-5 \mathrm{~km}$ stated visiting several times a year, as well as $43 \%$ of those who arrive from greater distance than $5 \mathrm{~km}$ to the nearest entrance. Pet walkers reached Grmoščica on foot, followed by the arrival by car and by bicycle, seldom using public transportation. Pet walkers who came to Grmoščica from its proximity (up to $1 \mathrm{~km}$ ) arrived on foot or use a bicycle just like the ones who came from a distance of $1-2 \mathrm{~km}$ from the nearest entry. For arrival from a distance of $2-5 \mathrm{~km}$ pet walkers used all means of transportation, while those who came from a greater distance of $5 \mathrm{~km}$ solely used a car as mean of transportation. They spent between one and two hours in the forest park.

The larger number of pet walkers did not perceive that their activities could cause conflicts with other visitors. Part of them assumed that their activities could interrupt cyclists. The same as previous types of visitors, the pet walkers as well did not perceive their activities as potentially harmful to nature. However, some of the users have stated concerns that dogs could chase away wild animals, while others were of opinion that if the dogs were on a leash, no damage could be done.

Visitors Who Spend Time in Forest Park with Their Families

This was the largest category of visitors. They are generally in the age group of $45-60$ years (Table 3 ). For the most part, they are well-educated and employed. Visitors in this category in similar share came to Grmoščica from a distance of up to $5 \mathrm{~km}$ and more than $5 \mathrm{~km}, 54 \%$ and $46 \%$ respectively. They visited Grmoščica several times per year or possibly several times per month. Regardless of the distance from the nearest entrance to Grmoščica, $68 \%$ of the respondents have reported visiting forest park several times a year, only those visitors who reported living at a distance of up to $1 \mathrm{~km}$ from the nearest entry came more frequently and reported weekly visits to the forest park. Majority of them arrived in Grmoščica by car or on foot, while the least of them used a bicycle. Those who live in the proximity of up to $2 \mathrm{~km}$ to the nearest entry mostly arrive to Grmoščica on foot, while those who need to cross over from 2 to up to 5 or more $\mathrm{km}$ to the nearest entrance mostly use a car and to a lesser extent public transportation. Visits by those who spend time in the forest park with their families lasts between an hour and two.
The majority of visitors who spend time in the forest park with their families did not think that their activities could cause conflicts with other visitors. Only some of them stated the possibility of conflicts with cyclists in the area. Because they reported not leaving any trash behind, they consider that their activities do not have a negative impact on nature.

\section{Perceived Problems and Suggestions for Improvement} of the Current State of Forest Park Grmoščica

Out of 91 respondents that answered the open-ended question about perceived problems in the forest park, 57 of them (62.6\%) noticed problems concerning Forest Park Grmoščica. Some of the most pronounced problems they expressed were problems related to waste - mostly illegal waste disposal (34 respondents perceived them). Visitors also highlighted neglect (15) manifested by the presence of weakly maintained buildings and forest paths. The third problem that users expressed (12) is the lack of equipment (benches, tables, trash bins) or lack of infrastructure (maintained and marked paths, hospitality facilities). Some of the respondents (3) stressed out the fact that the forest park is located at the landslide and there is a need for landslide management. In addition to these problems, the users indicated problems regarding construction works in the forest (4), behaviour of other users (3), excessive cutting (3), sewage (2), and accessibility of the forest park (1).

Besides questions about perceived problems and shortcomings, the respondents were asked about their support for installing new equipment and infrastructure in the forest park area. These possibilities were predefined and the respondents had three possible answers (Yes - on the entire site, Partially - only at entrances, No). The majority of the respondents agreed on placing new equipment and infrastructure in Forest Park Grmoščica, particularly new walking and bicycling paths, drinking water, new benches and tables (Figure 3 ). The respondents were not in favour of limiting the number of users on the site.

When asked about activities that should be developed in the future in a form of an open-ended question, 39 of the respondents stated that there was no need for new activities, while some addressed general activities such as sport (9) and recreational (4) activities, or, more specifically, cycling (19), jogging (4), spending time in nature (4) and walking (3). Furthermore, they stressed activities related to forest management (for instance planting trees, increased forest maintenance) (6), hospitality services (5), tourism (4) and education in nature (2). Also, some of the respondents suggested activities associated with protecting and observing nature, such as forest clean-up days (4), landslide management (4) and bird watching (2). Lastly, a few respondents stated activities for children (2), horseback riding (1), social activities (1) and relaxation (1).

Finally, the respondents were asked about the activities they think should be restricted in Forest Park Grmoščica in an open-ended question. About one third of the respondents (37 of them) stated that there were no such activities that should be restricted. Others emphasised the need for implementation of means to prevent illegal waste disposal 
Figure 3. The extent to which users support the installation of new infrastructure in Forest Park Grmoščica (N=91).

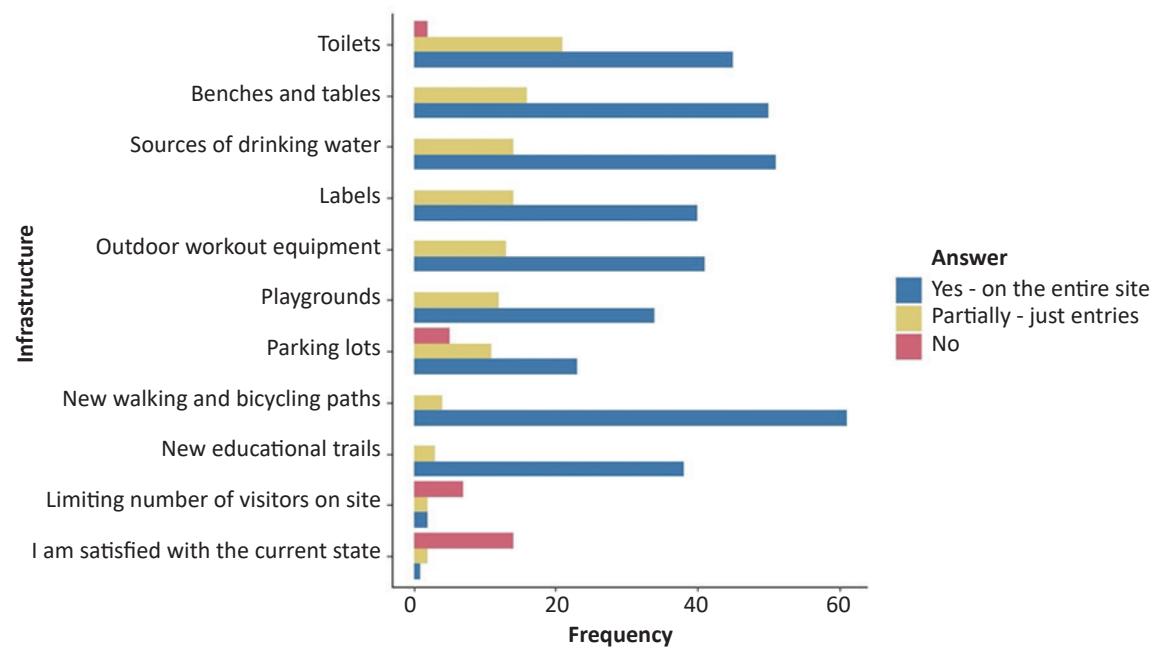

(16), limiting motor vehicle traffic in the forest park area (15) and restriction of all activities that damage the nature (12), as well as the restriction of construction work in the forest (9). Lastly, cutting (4), commercial activity (3), downhill biking and overcrowding (2) and other users' inadequate behaviour (1) were reported among the activities that should be restricted.

\section{DISCUSSION}

In order to manage and protect forest parks it is necessary to explore and quantify their social functions (Matić and Prpić 1997, Larondelle and Haase 2017). This research was conducted with the intention to improve Forest Park Grmoščica's planning and management with participation and inputs of forest park's users. The small number of respondents can be explained with the survey being administered during winter months, even though the survey was also available online. Scientific literature indicates that visiting forest parks is less frequent in winter than in summer months (Tyrväinen et al. 2003). In comparison to the general population of the city of Zagreb, gender distribution of the respondents was good. Distribution of age groups was relatively good, with the majority of the respondents in the age group of 45 to 60 years (Table 1 ). Representation of elderly citizens (above 60 years) in the sample is only $6 \%$, which is less than the amount of them in the general population (SYCZ 2019). Justification of that can be terrain configuration which can cause problems for the elderly, especially if they have trouble walking. Highly educated respondents were overrepresented in the sample (Table 1) in comparison to the general population (SYCZ 2019). However, this is common in other similar studies (Roovers et al. 2002, Lupp et al. 2016, Karanikola et al. 2017, Larondelle and Haase 2017).

The majority of users stated that they spend up to two hours in Forest Park Grmoščica (Table 2), what is also in line with similar research (Roovers et al. 2002). For the most part the users of Forest Park Grmoščica are citizens of local districts, meaning that they arrive from the forest park's proximity (Table 2). Accessibility of the forest or some other green space is essential for its recreational use (Hegetschweiler et al. 2017). Increasing the distance that users need to cross to use some green space for recreation decreases its use (Schipperijn et al. 2010). The majority of users of urban as well as rural forests are people living in their proximity (Meyer et al. 2019). Information such as visiting frequency, means of transportation to the forest park and entrances mostly used by visitors can help in planning the future infrastructure for visitors, as well as managing visitors themselves by separating users whose activities can potentially be in conflict (e.g. cyclists and pet walkers).

Recreation is often an underlying motivation for interaction with urban green spaces (Krajter Ostoić et al. 2020a). Walking is universally the most common recreational activity in forests (Roovers et al. 2002, Arnberger 2006, Gerstenberg et al. 2020, Krajter Ostoić et al. 2020a, Šodková et al. 2020). Visiting Forest Park Grmoščica to spend quality family time was a priority activity for most respondents (Figure 2). Likewise, this social activity is frequently mentioned as a highly-ranked activity and motivation for visiting the forest (Larondelle and Haase 2017, Getzner and Meyerhoff 2020), while taking pictures of nature is considerably less frequent (Šodková et al. 2020).

Visitors did not consider their activities in the forest park as being harmful for the nature because they leave no waste behind. Due to shortness of the survey, it was not upfront defined what a negative impact on nature is, hence the interpretation of the term was left to the respondents. Research shows that recreation in the forest can have a negative influence on forest ecosystem functioning. The mere presence of humans in a forest, regardless of the intensity of recreation, may have a negative impact on bird populations in the forest (Bötsch et al. 2018). Besides, users of urban forests show different off trail movement in 
relation to their recreational activity, with mountain bikers as the ones with most prominent probability of going off trail (Korpilo et al. 2018), while even walking outside the existing paths can have a negative impact on forest regeneration (Lehvävirta et al. 2014).

The great part of respondents noticed shortcomings and problems regarding Forest Park Grmoščica, with the illegal waste disposal in the forest as the most frequently expressed problem. This can have a significant influence on the quality of time spent in the forest (Ciesielski and Stereńczak 2018). Likewise, the presence of waste in the forest has a highly negative impact on the overall experience of forest recreation, even moderate quantity of waste induce users' reaction (Verlič et al. 2015). It is very important for green space users to have quality facilities and that locations that they visit are well maintained (Krajter Ostoić et al. 2017). This same study of the perception of green spaces by the citizens of Zagreb (survey conducted in 2013) shows that citizens as main problems recognize vandalism, lack of trash bins, lack of bicycle paths and behaviour of other green space users.

Visitors often express a need for additional equipment and infrastructure important for spending time in the forest such as trash bins, tables and benches, labels and other (Ciesielski and Stereńczak, 2018). Similar needs were expressed by visitors of Forest Park Grmoščica. Therefore, the majority of them supported the installation of new equipment and walking infrastructure (Figure 3).

There is a relation between forest management intensity and forest's recreational value, upon which users prefer small interventions in the forest to keep it "clean" rather than forests with no management applied (Edwards et al. 2012). Similarly, some users of Forest Park Grmoščica perceived it as neglected, due to some non-maintained and impassable parts of the forest. This confirms that the forest park needs to be managed in a proper way for it to be attractive to its users and fulfil its recreational function.

\section{CONCLUSIONS}

Forests with high recreational value should be managed in a way that they continuously provide services of recreation and relaxation for their users. Ideally, management should involve the perspective of visitors and potential visitors of such forests. This way information about user's perception, preferences, needs as well as suggestions for improvements can be collected as an important input for further planning and management. Urban green spaces with their multiple ecosystem services contribute to the perception of wellbeing and quality of life (Haase et al. 2014). Regarding the positive role of recreational use of green spaces on the health of all age groups there is an imperative for planning and management of urban green spaces to encourage their recreational use. This survey with visitors and users of Forest Park Grmoščica serves as an example of good practice and improvement of the existing way of planning and management of forest parks of the city of Zagreb. It should certainly become common practice in planning and management of other forest parks and other urban green space in the future.

\section{Author Contributions}

IK, NM and SŠ collected the data. MK processed the data and performed the statistical analyses and prepared tables and figures. All authors interpreted the results. MK, AMM, DV and SKO drafted the manuscript.

\section{Funding}

The work on the paper was supported by INTERREG DANUBE's project "Management and Utilization of Urban Forests as Natural Heritage in Danube Cities" (URBforDAN). Work by Martina Kičić, Ana Marija Marin and Silvija Krajter Ostoić was supported by the project "Improving Green Infrastructure Planning and Management through Participatory Mapping of Cultural Ecosystem Services" (CULTUR-ES) funded by Croatian Science Foundation (project number UIP-201705-1986). Work by Ana Marija Marin was additionally supported by project "Young Researchers' Career Development Project-Training New Doctoral Students" (project number DOK-2020-01-6490) funded by Croatian Science Foundation.

\section{Acknowledgments}

The authors would like to thank those who participated in the survey, as well as those who administered the survey (City of Zagreb and Croatian Forests Ltd.). Without their time and effort, the research would not be possible.

\section{Conflicts of Interest}

The authors declare no conflict of interest.

\section{Supplementary Materials}

Supplementary File 1. URBforDAN project - Survey for users of Forest Park Grmoščica.

\section{REFERENCES}

Aasetre J, Gundersen V, Vistad OI, Holtrop EJ, 2016. Recreational preferences along a naturalness-development continuum: Results from surveys in two unequal urban forests in Europe. J Outdoor Recreat Tour 16: 58-68. https://doi.org/10.1016/i. jort.2016.09.006.

Agimass F, Lundhede T, Emil T, Bredahl J, 2017. The choice of forest site for recreation: A revealed preference analysis using spatial data. Ecosyst Serv 31: 445-454. https://doi. org/10.1016/i.ecoser.2017.11.016.
Anić I, Oršanić M, 2010. Morphological and Silvicultural Properties of the Park Forests of Zagreb. In: Matić S, Anić I (eds) Park Forests of the City of Zagreb. Academy of Forestry Sciences, Zagreb, Croatia, pp. 147-158.

Arnberger A, 2006. Recreation use of urban forests: An inter-area comparison. Urban For Urban Gree 4(3-4): 135-144. https:// doi.org/10.1016/i.ufug.2006.01.004. 
Arnberger A, Eder R, 2007. Monitoring recreational activities in urban forests using long-term video observation. For An Int J For Res 80(1): 1-15. https://doi.org/10.1093/forestry/cpl043.

Bethmann S, Simminger E, Baldy J, Schraml U, 2018. Forestry in interaction. Shedding light on dynamics of public opinion with a praxeological methodology. For Policy Econ 96: 93-101. https://doi.org/10.1016/i.forpol.2018.08.005.

Bötsch Y, Tablado Z, Scherl D, Kéry M, Graf RF, Jenni L, 2018. Effect of recreational trails on forest birds: Human presence matters. Front Ecol Evol 6: 175. https://doi.org/10.3389/ fevo.2018.00175.

Ciesielski M, Stereńczak K, 2018. What do we expect from forests? The European view of public demands. J Environ Manage 209: 139-151. https://doi.org/10.1016/i.jenvman.2017.12.032.

Creswell JW, 2003. Research design: Qualitative, quantitative, and mixed method approaches, $2^{\text {nd }}$ edn. SAGE Publications, Thousand Oaks, California, 246 p.

De Leeuw E, 2005. To Mix or Not to Mix Data Collection Modes in Surveys. J Off Stat 21(5): 233-255.

Dou Y, Zhen L, De Groot R, Du B, Yu X, 2017. Assessing the importance of cultural ecosystem services in urban areas of Beijing municipality. Ecosyst Serv 24: 79-90. https://doi. org/10.1016/i.ecoser.2017.02.011.

Edwards DM, Jay M, Jensen FS, Lucas B, Marzano M, Montagné C, Peace A, Weiss G, 2012. Public Preferences Across Europe for Different Forest Stand Types as Sites for Recreation. Ecol Soc 17(1): 27. https://doi.org/10.5751/es-04520-170127.

Gerstenberg T, Baumeister CF, Schraml $U$, Plieninger $T$, 2020. Hot routes in urban forests: The impact of multiple landscape features on recreational use intensity. Landscape Urban Plan 203: 103888. https://doi.org/10.1016/i. landurbplan.2020.103888.

Getzner M, Meyerhoff J, 2020. The benefits of local forest recreation in austria and its dependence on naturalness and quietude. Forests 11(3): 1-23. https://doi.org/10.3390/ f11030326.

Haase D, Larondelle N, Andersson E, Artmann M, Borgström S, Breuste J, Gomez-Baggethun E, Gren Å, Hamstead Z, Hansen $\mathrm{R}$, Kabisch N, Kremer P, Langemeyer J, Rall EL, McPhearson T, Pauleit S, Qureshi S, Schwarz N, Voigt A, Wurster D, Elmqvist $T, 2014$. A quantitative review of urban ecosystem service assessments: Concepts, models, and implementation. Ambio 43(4): 413-433. https://doi.org/10.1007/s13280-014-0504-0.

Hegetschweiler KT, de Vries S, Arnberger A, Bell S, Brennan M, Siter N, Olafsson AS, Voigt A, Hunziker M, 2017. Linking demand and supply factors in identifying cultural ecosystem services of urban green infrastructures: A review of European studies. Urban For Urban Gree 21: 48-59. https://doi. org/10.1016/j.ufug.2016.11.002.

Kabisch N, Qureshi S, Haase D, 2015. Human-environment interactions in urban green spaces - A systematic review of contemporary issues and prospects for future research. Environ Impact Assess 50: 25-34. https://doi.org/10.1016/j. eiar.2014.08.007.

Karanikola P, Panagopoulos T, Tampakis S, 2017. Weekend visitors' views and perceptions at an urban national forest park of Cyprus during summertime. J Outdoor Recreat Tour 17: 112-121. https://doi.org/10.1016/j.jort.2016.10.002.

Korpilo S, Virtanen T, Saukkonen T, Lehvävirta S, 2018. More than $A$ to $B$ : Understanding and managing visitor spatial behaviour in urban forests using public participation GIS. $J$ Environ Manage. 207: 124-133. https://doi.org/10.1016/i. jenvman.2017.11.020.

Krajter Ostoić S, 2013. Analysis of current urban forest governance in the City of Zagreb, PhD Thessis, University of Zagreb, Faculty of Forestry, Zagreb, Croatia, $268 \mathrm{p}$.
Krajter Ostoić S, Konijnendijk van den Bosch CC, Vuletić D, Stevanov M, Živojinović I, Mutabdžija-Bećirović S, Lazarević J, Stojanova B, Blagojević D, Stojanovska M, Nevenić R, Pezdevšek Malovrh Š, 2017. Citizens' perception of and satisfaction with urban forests and green space: Results from selected Southeast European cities. Urban For Urban Gree 23: 93-103. https://doi.org/10.1016/j.ufug.2017.02.005.

Krajter Ostoić S, Marin AM, Kičić M, Vuletić D, 2020a. Qualitative exploration of perception and use of cultural ecosystem services from tree-based urban green space in the city of Zagreb (Croatia). Forests 11(8): 876. https://doi.org/10.3390/ f11080876.

Krajter Ostoić S, Vuletić D, Planinšek Š, Vilhar U, Japelj A, 2020b. Three Decades of Urban Forest and Green Space Research and Practice in Croatia and Slovenia. Forests 11(2): 136. https:// doi.org/10.3390/f11020136.

Larondelle N, Haase D, 2017. Back to nature! Or not? Urban dwellers and their forest in berlin. Urban Ecosyst 20(5): 10691079. https://doi.org/10.1007/s11252-017-0660-7.

Lehvävirta S, Vilisics F, Hamberg L, Malmivaara-Lämsä M, Kotze DJ, 2014. Fragmentation and recreational use affect tree regeneration in urban forests. Urban For Urban Gre. 13(4), 869-877. https://doi.org/10.1016/j.ufug.2014.10.003.

Lupp G, Förster B, Kantelberg V, Markmann T, Naumann J, Honert $C$, Koch M, Pauleit S, 2016. Assessing the recreation value of urban woodland using the ecosystem service approach in two forests in the munich metropolitan region. SustainabilityBasel 8(11): 1156. https://doi.org/10.3390/su8111156.

Matić S, 2010. Park Forests of the City of Zagreb, $1^{\text {st }}$ edn. Academy of Forestry Sciences, Zagreb, Croatia, $200 \mathrm{p}$.

Matić S, Prpić B, 1997. Program njege, obnove i održavanja, te ekološke i socijalne funkcije park-šuma na području grada Zageba. Sumar List 121(5-6): 225-242.

Meyer MA, Rathmann J, Schulz C, 2019. Spatially-explicit mapping of forest benefits and analysis of motivations for everydaylife's visitors on forest pathways in urban and rural contexts. Landscape Urban Plan 185: 83-95. https://doi.org/10.1016/i. landurbplan.2019.01.007.

Mravunac I, 2015. City Park Grmoščica in Zagreb. MSc thesis, University of Zagreb, Faculty of Architecture, Zagreb, Croatia, $100 \mathrm{p}$.

Ordóñez Barona C, 2015. Adopting public values and climate change adaptation strategies in urban forest management: A review and analysis of the relevant literature. J Environ Manage 164: 215-221. https://doi.org/10.1016/i. jenvman.2015.09.004.

Posavec S, 2020. Integrirani višenamjenski plan upravljanja (IMMP) urbanim šumama Grada Zagreba [Power point presentation], Predstavljanje prijedloga Integriranog višenamijenskog plana upravljanja urbanim šumama Grada Zagreba, Zagreb.

Reed MS, 2008. Stakeholder participation for environmental management: A literature review. Biol Conserv 141(10): 24172431. https://doi.org/10.1016/j.biocon.2008.07.014.

Roovers P, Hermy M, Gulinck H, 2002. Visitor profile, perceptions and expectations in forests from a gradient of increasing urbanisation in central Belgium. Landscape Urban Plan 59(3): 129-145. https://doi.org/10.1016/S0169-2046(02)00011-7.

Schipperijn J, Ekholm O, Stigsdotter UK, Toftager M, Bentsen P, Kamper-Jørgensen F, Randrup TB, 2010. Factors influencing the use of green space: Results from a Danish national representative survey. Landscape Urban Plan 95(3): 130-137. https://doi.org/10.1016/i.landurbplan.2009.12.010.

Statistical Yearbook of the City of Zagreb for 2019

Šimpraga S, 2011. Zagreb, javni prostor (Zagreb, Public Space). Porfirogenet, Zagreb, Croatia, $512 \mathrm{p}$. 
Šodková M, Purwestri RC, Riedl M, Jarský V, Hájek M, 2020. Drivers and frequency of forest visits: Results of a national survey in the Czech Republic. Forests 11(4): 414. https://doi. org/10.3390/F11040414.

Tyrväinen L, Silvennoinen $\mathrm{H}$, Kolehmainen O, 2003. Ecological and aesthetic values in urban forest management. Urban For Urban Gree 1(3): 135-149. https://doi.org/10.1078/16188667-00014.

Verlič A, Arnberger A, Japelj A, Simončič P, Pirnat J, 2015. Perceptions of recreational trail impacts on an urban forest walk: A controlled field experiment. Urban For Urban Gree 14(1): 89-98. https://doi.org/10.1016/i.ufug.2014.12.004.
1KA, 2018. URBforDAN projekt - Upitnik za "Korisnike urbane šume Grmoščica". Available online: https://www.1ka. si/a/195549.

$\mathrm{R}$ Core Team, 2019. R: A language and environment for statistical computing. R Foundation for Statistical Computing, Vienna, Austria. Available online: https://www.R-project.org/.

URBforDAN, 2018. Available online: http://www.interregdanube.eu/approved-projects/urbfordan. 